\title{
Identifikasi Mutasi FecX Pada Gen BMP15 dan Pengaruhnya Terhadap Sifat Prolifik pada Kambing Lokal di Kabupaten Lombok Barat
}

\section{(Identification of Mutation on Gene FecX BMP15 and its Effects on Prolific Nature of Local Goats in West Lombok Regency)}

\author{
Rahmat Agus Hidayat ${ }^{1)}$, Sulaiman Ngongu Depamede ${ }^{2)}$, Maskur ${ }^{3)}$ \\ ${ }^{1)}$ Program Magister Manajemen Sumberdaya Peternakan Universitas Mataram \\ ${ }^{2)}$ Laboratorium Mikro-biotek Fakultas Peternakan Universitas Mataram \\ 3) Laboratorium Genetika dan Pemuliaan Ternak Fakultas Peternakan Universitas Mataram \\ Jalan Majapahit 62 Mataram Lombok, Indonesia. \\ Telepon: (0370) 633603. Fax: (0370) 640592 \\ Email: rahmat.agus78@yahoo.com
}

Diterima : 24 Maret 2015/ Disetujui: 4 Mei 2015

\begin{abstract}
The aims of this study were to identify the mutations of FecX gene in the local goats and to analyze its polymorphism as well as its influence on the prolific nature of the local goats in West Lombok Regency, Indonesia. The study was conducted in the Immunobiology Laboratory of Mataram University, using DNA isolated from 100 blood samples of local female goats which have given birth of once to three times. The methods used were PCR-RFLP method and the PCR products were digested with HinfI restriction enzyme (G|ANTC) then analyzed visually based on DNA banding patterns on $2 \%$ agarose gels. The frequency of allele and genotype obtained, were then analyzed through a comparison with the secondary data of litter size obtained from the local goat keepers information. The results showed that the gene mutation of FecX ${ }^{\mathrm{G}}$ produced two alleles: "wild-type" (+) sized of $110 \mathrm{bp}$ and $31 \mathrm{bp}$, and the mutant allele $(\mathrm{G})$ of $141 \mathrm{bp}$ with the allele frequency of 0,965 and 0,035 respectively. Combinations of alleles in the gene BMP15 produced two genotypes, namely (a) genotype $++(110 \mathrm{bp} / 110 \mathrm{bp})$ with a frequency of 0.93 , with the average litter size of $1.59 \pm 0.319$, and (b) genotype $G+(141 \mathrm{bp} / 110 \mathrm{bp})$, with a frequency of 0.07 and with the average litter size of $1.65 \pm 0.202$. The results of this study indicated that mutation occurred in BMP15 gene, i.e. FecX ${ }^{\mathrm{G}}$ gene, the gene responsible for the prolificacy of animals studied. Furthermore there was a correlation between polymorphism of $\mathrm{FecX}^{\mathrm{G}}$ gene and the prolific nature of the local goats, which was predicted to lead the divergence in litter size of each local goat genotype.
\end{abstract}

Key -words: mutation, BMP15, local goat.

\section{PENDAHULUAN}

Kambing lokal di Indonesia yang umum adalah kambing kacang sebagai kambing asli Indonesia dan kambing-kambing hasil persilangan antara kambing kacang dengan kambing lainnya, seperti dengan kambing etawah atau peranakan etawah (PE). Salah satu hasil persilangan kambing kacang deangan kambing PE adalah kambing batang (Wijoseno, 2009). Jenis kambing ini secara fisik miripkambing PE tetapi ukuran tubuhnya lebih kecil daripada kambing PE dan lebih besar daripada kambing kacang.
Kambing kacang, meskipun beruk-uran relative kecil, memiliki sifat reproduksi cukup tinggi (prolifik) dan mampu beradaptasi dengan baik di lingkungan yang sangat sederhana (Pamungkas et al.,2009). Sifat prolifik merupakan sifat bereproduksi atau kemampuan melahirkan anak lebih dari satu ekor per kelahiran. Sifat prolifik setiap individu kambing, berbeda-beda disebabkan oleh adanya variasi genetik yang menyebabkan peningkatan kecepatan ovulasi dan jumlah anak per kelahiran (litter size). Jumlah anak per kelahiran menentukan laju peningkatan populasi ternak kambing. 
Gen bone morphogenetic protein 15 (BMP15) atau yang sering disebut $\mathrm{FecX}$ (fecundity chromosome $X$ ) merupakan gen yang mengendalikan sifat prolifik pada berbagai jenis domba. Menurut Chu et al. (2007) pola pengontrolan gen terhadap mekanisme prolifik mengindikasikan adanya perbedaan antara breed kambing dan domba, tetapi sifat prolifik pada kambing dan domba masih dikontrol oleh gen yang sama yaitu BMP 15 .

Studi tentang mekanisme gen BMP-15 sebagai marker pembantu seleksi pada program breeding ternak domba sudah banyak dilakukan. Pada ternak kambing, informasi mengenai potensi dan pemanfaatan gen ini sebagai kandidat gen untuk sifat prolifik belum banyak dilaporkan, maka dilakukan pengembangan marker seleksi melalui identifikasi mutasi gen FecX dan pengaruhnya terhadap sifat prolifik pada kambing lokal.

Penelitian ini bertujuan untuk mengidentifikasi mutasi gen FecX pada ternak kambing lokal dan menganalisis polimorfisme gen FecX serta pengaruh-nya terhadap sifat Prolifik pada kambing lokal.

\section{Lokasi penelitian}

\section{MATERI DAN METODE}

Penelitian ini dilakukan di Laboratorium Immunobiologi Universitas Mataram. Materi utama penelitian berupa DNA yang diisolasi dari sampel darah 100 ekor kambing lokal betina dewasa yang sudah melahirkan 2-3 kali dan dipelihara secara tradisional oleh peternak di Kabupaten Lombok Barat.

Identifikasi mutasi gen FecX dilakukan menggunakan teknik PCR-RFLP (polymerase chain reactionreaction fragment length polymorphism), seperti yang dilakukan oleh Davis et al. (2002), Chu et al. (2007), dan Maskur et al. (2010). Teknik ini sudah digunakan secara meluas pada berbagai uji DNA.

\section{Isolasi DNA sampel darah kambing}

Isolasi DNA darah kambing dilakukan berdasarkan metode yang digunakan oleh Maskur et al. (2010) dengan menggunakan buffer lisis untuk mendegradasi dinding sel dan fenol-khloroform untuk mendegradasi protein dan lemak, kemudian dipresipitasi menggunakan etanol absolute, dan diikuti dengan perlakuan
RNAse untuk memperoleh DNA yang bebas RNA.

\section{Amplikasi PCR gen BMP 15}

Gen BMP 15 diamplifikasi dengan teknik PCR menggunakan Primer gen BMP-15 yang didesain berdasarkan informasi sekuen yang digunakan sebelumnya oleh Chu et al. (2007), dengan sekuen Forward: 5' CACTGTCTTCTT GTTACTGTATTTCAATGAC-3', dan Reverse: 5'GATGCAATACTGCCTGCTTG 3'.

Amplifikasi dilakukan mengikuti metode yang digunakan sebelumnya oleh Davis et al. (2002) dan Chu et al. (2007), sebanyak 35 siklus, meliputi siklus pertama adalah predenaturasi pada suhu $95^{\circ} \mathrm{C}$ selama 5 menit, diikuti denaturasi $95^{\circ} \mathrm{C}$ selama 45 detik, dilanjutkan dengan anelling $63^{\circ} \mathrm{C}$ selama 45 detik, dan ekstensi $72{ }^{\circ} \mathrm{C}$ selama 1 menit kemudian diakhiri satu siklus berikutnya pada ekstensi akhir $72^{\circ} \mathrm{C}$ selama 10 menit (Chu et al., 2007).

\section{Deteksi mutasi gen BMP 15}

Deteksi mutasi gen BMP15 dilakukan melalui tehnik RFLP (restriction fragment length polymer-phism) menggunakan enzim restriksi HinfI. Produk PCR gen BMP 15 serta pereaksi diinkubasi di dalam inkubator pada suhu $37^{\circ} \mathrm{C}$ selama $16-18$ jam. Pengamatan terhadap mutasi alel gen dilakukan secara visual berdasarkan pada hasil elektroforesis gel agarose $2 \%$ menggunakan ethidium bromide, dengan bantuan Gel documentation and Analysis Systems, sebagaimana dilakukan Chen et al. (2007), dengan beberapa modifikasi.

\section{Analisis statistik}

Analisis terhadap frekuensi alel dan frekuensi genotype dilakukan berdasarkan Maskur et al., (2010), sementara keseimbangan Hardy Weinberg diuji dengan uji $\chi^{2}$ dilakukan berdasarkan Hartl dan Clark, (1997). Selanjutnya, heterozigositas pengamatan (Ho), heterozigositas harapan $(\mathrm{He})$ dan standar eror heterozigositas harapan serta nilai PIC dianalisa menurut Weir, (1996) dan perbedaan rataan litter size antara genotipe fragmen gen $B M P-15$ dianalisis dengan uji $t$ (Mendenhall, 1987).

\section{Frekuensi alel}


Frekuensi alel dihitung berdasarkan rumus Nei (1987) dan Nei dan Kumar (2000) sebagai berikut:

$$
x_{\mathrm{i}}=\frac{\left(2 n_{i i}+\sum_{\mathrm{j}=1} n_{i j}\right)}{(2 \mathrm{~N})}
$$

Ket :

$x \mathrm{i}=$ = frekuensi alel ke-i

nii $\quad=$ jumlah individu bergenotipe ii

nij $\quad=$ jumlah individu bergenotipe $i \mathrm{j}$

$\mathrm{N}=$ jumlah individu sampel

\section{Frekuensi genotipe}

Frekuensi genotipe dihitung dengan rumus:

$$
\begin{aligned}
& x_{i}=\frac{\sum_{\mathrm{i}=1}^{\mathrm{n}} \mathbf{n}_{\mathrm{i}}}{\mathrm{N}} \\
& x_{i}=\frac{\sum_{\mathrm{i}=1}^{\mathrm{n}} \mathbf{n}_{\mathrm{i}}}{\mathrm{N}}
\end{aligned}
$$

Ket.: $x i=$ frekuensi genotipe ke-I; $n i=$ jumlah individu bergenotipe $\mathrm{I}, N=$ jumlah individu sampel

\section{HASIL DAN PEMBAHASAN}

\section{Amplifikasi gen BMP15}

Amplifikasi gen BMP15 pada kambing lokal menghasilkan DNA target (produk PCR) dengan panjang produk $141 \mathrm{bp}$ (Gambar 1).

Hasil ini sesuai dengan panjang produk pada Sekuens gen BMP-15 pada kromosom X (Gen Bank dengan kode akses NC_022322). Hasil ini menunjukkan bahwa kondisi optimum PCR yang digunakan pada penelitian ini terhadap DNA yang diisolasi dari darah kambing local cukup memadai.

\section{Mutasi gen BMP15 pada kambing lokal}

Hasil identifikasi mutasi gen BMP15 pada kambing lokal dilakukan dengan metode PCRRFLP menggunakan enzim restriksi HinfI sebagai pemotong, dengan situs pemotong G|ANTC (Gambar 2).

Mutasi gen BMP15 yang terjadi menimbulkan polimorfisme genotipe gen $\mathrm{FecX}^{\mathrm{G}}$ pada kambing Lokal. Hasil penelitian ini sama dengan hasil penelitian yang dilaporkan oleh Maskur et al. (2010). Hasil ini menunjukkan adanya indikasi bahwa kambing lokal membawa mutasi Fec $\mathrm{X}^{\mathrm{G}}$ dari gen BMP15, seperti yang dijumpai pada domba Han ekor tipis (Chu et al., 2007) dan domba Lombok ekor gemuk (Maskur et al., 2010). Adanya mutasi gen $\mathrm{FecX}^{\mathrm{G}}$ mengakibatkan polimorfisme gen BMP15 pada kambing Lokal, yang menghasilkan dua genotip yaitu ++ (homozigot wild type) dan G+ (heterozigot). Menurut Chu et al. (2007) mutasi yang terjadi pada gen BMP15 menyebabkan terjadinya premature akibat danya stop codon pada asam amino ke 239 (Q239R) dan menghasilkan alel G (Maskur et al., 2010).

Mutasi yang terjadi pada gen BMP15 disebabkan oleh perubahan basa. Menurut Chu et al. (2007) bahwa mutasi gen BMP15 yang terjadi pada domba merupakan perubahan (transisi) basa sitosin (C) menjadi timin (T) pada posisi 718. Perubahan basa $\mathrm{C}$ menjadi $\mathrm{T}$ pada sekuens gen BMP15 dapat dilihat pada Gambar 3.

Pada penelitian ini tidak dilakukan sekuensi terhadap produk-produk PCR hasil pemotongan menggunaan HinfI. Akan tetapi, sebagai acuan informasi sekuens gen BMP15 (Gene Bank) dengan situs pemotongan enzim retriksi HinfI(G|ANTC) berada pada posisi basa ke 31 $\mathrm{pb}$ yang menye-babkan perubahan asam amino pada kodon 131 dari start codonexon 2 dan posisi nukleotida $6031 \mathrm{pb}$ (Gambar 3). Perubahan asam amino $(\mathrm{CAG}=$ Glutamine $-\mathrm{TAG}=$ Stop codon $)$ menunjukkan bahwa terjadinya mutasi pada gen BMP15 yang menyebabkan perubahan asam amino.

Perubahan asam amino meng-akibatkan kehilangan fungsi pada BMP15 yang menghambat ekspresiresptor FSH (follicle stimulating hormone) pada granulosa cells menurun sehingga membuka peluang sensitifitas FSH menjadi lebih tinggi dan meningkatkan ekspresi dari gen BMP15 (Davis, 2005).

Hubungan mutasi BMP15 dengan laju ovulasi berdasarkan pada konsep bahwa meningkatkan aktivitas BMP15 yang direduksi, laju ovulasi semakin meningkat, akan tetapi apabila level BMP15 terlalu rendah akan menyebabkan tidak berfungsi secara total (Fabre et al., 2006). 


\section{$\begin{array}{lllllllllll}1 & 2 & 3 & 4 & \text { M } & 5 & 6 & 7 & 8 & 9 & 10\end{array}$}

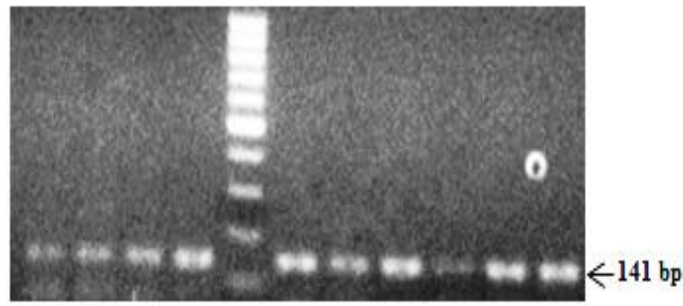

Gambar 1. Representasi visualisasi hasil amplifikasi PCR gen BMP 15 kambing Lokal pada gel agarose $2 \%$.

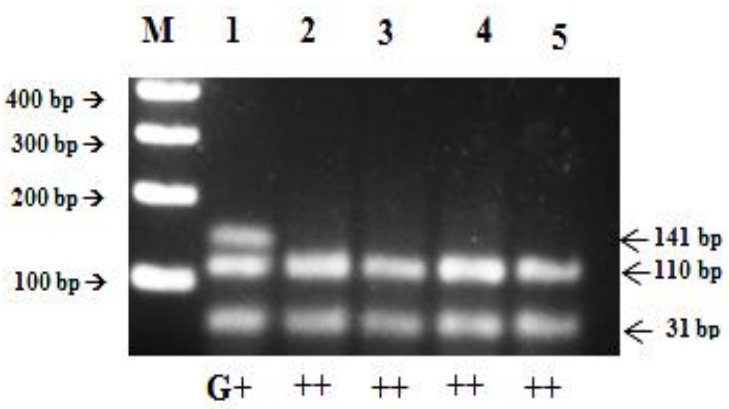

Gambar 2. Mutasi $\mathrm{FecX}^{\mathrm{G}}$ gen BMP15 yang dipotong dengan enzim HinfI.

Ket: $\mathrm{M}($ marker $)=$ Ladder $100 \mathrm{bp} ; \mathrm{G}+(1)=$ Individu heterozigot (141 bp,110 bp dan $31 \mathrm{bp}$ );

$++(2,3,4,5)=$ Individu homozigot wild type $(110 \mathrm{bp}$ dan $31 \mathrm{bp}$ )

\section{Frekuensi alel dan genotipe gen BMP15}

Analisis keragaman gen BMP15 menghasilkan alel + dan $\mathrm{G}$ yang memiliki genotipe ++ (wild type) dan $\mathrm{G}+$, sedangkan genotipe $\mathrm{GG}$ (homo-zigot mutan) tidak ditemukan pada kambing Lokal (Tabel 1). Hasil penelitian ini sama dengan hasil penelitian yang dilakukan oleh Maskur et al., (2010) pada domba Lombok ekor gemuk.

Selanjutnya, tampak pula pada Tabel 1 bahwa frekuensi alel + pada gen BMP15 lebih tinggi dibandingkan dengan alel G. Frekuensi alel + sebesar 0,965 dan alel G sebesar 0,035. Hasil penelitian ini sama dengan hasil penelitian yang dilaporkan oleh Chu et al. (2007) yaitu pada gen BMP15 menunjukkan hasil frekuensi alel + lebih tinggi daripada frekuensi alel G. Hal ini mengindikasikan bahwa kandidat gen BMP15 yang terdapat pada berbagai jenis domba ditemukan juga pada kambing local, dengan nilai $>1 \%$. Deangan demikian maka gen
BMP15 pada kambing kokal dapat dikategorikan bersifat polimorfik karena nilai frekuensi alel nya lebih dari 1\% (Nei dan Kumar, 2000).

Hasil analisis uji Chi-square $\left(\mathrm{X}^{2}\right)$ terhadap gen BMP15 menunjukkan bahwa frekuensi genotipe dan frekuensi alel adalah homogen atau seimbang terhadap populasi ternak kam-bing lokal. Hasil ini menunjukkan bahwa populasi kambing lokal masih berada dalam keadaan seimbang (keseimbangan Hardy Weinberg) dan menunjukkan pada populasi ternak kambing lokal belum pernah dilakukan seleksi.

Hasil pengamatan di lokasi penelitian menunjukkan bahwa populasi kambing lokal dipelihara secara tradisional, tidak pernah dilakukan seleksi terhadap ternak yang dipelihara, terutama seleksi berdasarkan jumlah anak sekelahiran.

\section{Pendugaan nilai heterozigositas dan PIC gen BMP15.}

Nilai heterozigositas pengamatan $\left(\mathrm{H}_{\mathrm{o}}\right)$ disajikan pada Tabel 2 yaitu 0,070 lebih tinggi dibandingkan nilai heterozigositas harapan $\left(\mathrm{H}_{\mathrm{e}}\right)$ sebesar 0,068. Hasil ini menunjukkan bahwa heterozigositas pengamatan dan nilai heterozigositas harapan pada kambing lokal tidak menunjukkan adanya perbedaan yang besar pada fragmen gen BMP15.

Menurut Tambasco et al.(2003), perbedaan antara nilai heterozigositas pengamatan $(\mathrm{Ho})$ dan nilai hetero-zigositas harapan $(\mathrm{He})$ dapat dijadikan indikator adanya ketidak-seimbangan genotipe pada populasi yang diamati. Nilai heterozigositas pengamatan (Ho) dan heterozigositas harapan $(\mathrm{He})$ ini juga dapat digunakan untuk menduga nilai inbreeding pada suatu kelompok ternak. Nei (1987) menyatakan bahwa nilai heterozi-gositas ditentukan oleh jumlah sampel yang digunakan, jumlah dan nilai frekuensi, serta faktor yang mempengaruhi tinggi rendahnya nilai heterozigositas pada populasi ternak yang disebabkan oleh perkawinan acak atau peluang inbreeding yang rendah.

Nilai polymorphic information contents (PIC) merupakan salah satu parameter yang menunjukkan tingkat informatifnya suatu marker/penciri. Klasifikasi nilai PIC yaitu $\mathrm{PIC} \leq 0,25$ polimorfisme rendah, $0,25 \leq \mathrm{PIC} \leq 0,5$ 


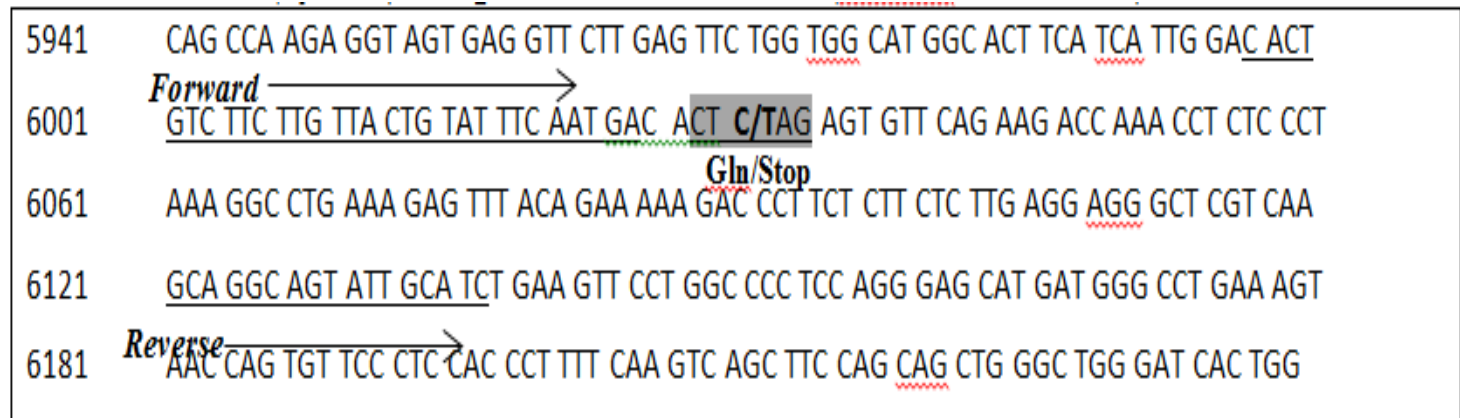

Gambar 3 : Sekuens gen BMP15 pada kambing (Gen Bank dengan kode akses $J Q 350891.1)$.

Keterangan : Posisi primer (bergaris bawah), perubahan basa/ asam amino (cetak tebal) dan situs pemotongan (bergaris bawah warna abu-abu).

Tabel 1. Frekuensi genotip dan alel gen BMP15 pada kambing Lokal

\begin{tabular}{|c|c|c|c|c|c|c|c|}
\hline \multirow[t]{3}{*}{ Gen } & \multicolumn{5}{|c|}{ Frekuensi } & \multirow{3}{*}{$\mathrm{X}^{2}$ (HWE) } & \multirow{3}{*}{$X^{2}(0.05)$} \\
\hline & \multicolumn{3}{|c|}{ Genotipe } & \multicolumn{2}{|c|}{ Alel } & & \\
\hline & $\overline{G G}$ & $\mathrm{G}+$ & ++ & $\bar{G}$ & + & & \\
\hline BMP15 & $0,00(0)$ & $0,07(7)$ & $0,93(93)$ & 0,035 & 0,965 & $0,132^{*}$ & 3,841 \\
\hline
\end{tabular}

Keterangan : * $=\mathrm{X}_{\text {hitung }}^{2}<\mathrm{X}_{\text {tabel }(0.05)(1)}^{2}$

Tabel 2. Nilai heterozigositas pengamatan $\left(\mathrm{H}_{\mathrm{o}}\right)$, heterozigositas harapan $\left(\mathrm{H}_{\mathrm{e}}\right)$, dan polymorphic information contents (PIC) gen BMP15 pada kambing lokal

\begin{tabular}{lcccc}
\hline Gen & $\mathrm{N}$ & $\mathrm{Ho}$ & $\mathrm{He} \pm \mathrm{Se}$ & $\mathrm{PIC}$ \\
\hline BMP15 & 100 & 0.070 & $0.068 \pm 0.031$ & 0.069 \\
\hline Keterangan : & $\mathrm{N}:$ jumlah ternak & & &
\end{tabular}

Tabel 3. Rata-rata nilai litter size pada kambing lokal dengan gen BMP15

\begin{tabular}{ccc}
\hline Genotipe BMP15 & Jumlah Ternak & Litter Size \\
\hline G+ & 7 & $1,65 \pm 0,202^{\mathrm{a}}$ \\
++ & 93 & $1,59 \pm 0,319^{\mathrm{b}}$ \\
\hline
\end{tabular}

Keterangan : $(\mathrm{a}-\mathrm{b})=$ Rata-rata dengan superskrip yang beda menunjukkan beda nyata $(\mathrm{P}<0.05)$

Rahmat Agus Hidayat, Sulaiman Ngongu Depamede, Maskur (Identifikasi Mutasi FecX...) 
polimorfisme sedang, dan $\mathrm{PIC} \geq 0,5$ polimorfisme tinggi.

Selanjutnya, pada Tabel 2 tampak pula bawa hasil analisis nilai PIC gen BMP15 adalah 0,069. Hasil ini menggambarkan bahwa polimerfisme genetik gen BMP15 pada populasi kambing lokal berada pada level rendah. Berdasarkan nilai PIC tersebut maka gen BMP15 memiliki potensi yang rendah sebagai penciri/marker genetik untuk sifat prolifik pada kambing lokal. Selain itu, nilai PIC juga digunakan untuk menentukan ada tidaknya alel yang polimorfik.

\section{Hubungan polimorfisme gen BMP 15 terhadap sifat prolifik kambing local}

Hasil penelitian menunjukkan bahwa ratarata jumlah anak sekelahiran atau litter size pada kambing lokal yaitu 1,60 ekor/induk/kelahiran. Hasil data kelahiran yang diperoleh pada penelitian ini yaitu induk beranak antara 2-3 kali dengan kisaran 29\% (29 ekor) induk beranak tunggal, 69\% (69 ekor) induk pernah beranak kembar (twins) dan $10 \%$ (10 ekor) induk pernah beranak 3 (triplets) lebih tinggi dengan yang dilaporkan oleh Pamungkas et al. (2009) bahwa tingkat kesuburan kambing kacang cukup tinggi dengan kemampuan hidup dari lahir sampai sapih $79,4 \%$, sifat prolifik anak kembar dua $52,2 \%$, kembar tiga 2,6\% dan anak tunggal 44,9\%. Hasil rata-rata litter size pada kambing lokal dengan gen BMP15 dapat dilihat pada Tabel 3.

Menurut Davis (2005) gen BMP-15 merupakan gen yang menyebabkan kenaikan laju ovulasi pada betina dalam keadaan heterozigot dan menyebabkan infertill pada betina dalam keadaan homozigot. Sedangkan menurut Hamdan et al. (2012) jumlah anak yang dilahirkan oleh seekor ternak sangat tergantung dari jumlah sel telur yang diovulasikan setiap siklusnya dan berkaitan dengan sekresi hormon follicle stimulating hormone (FSH) pada saat folikulogenesis. Selanjutnya dijelaskan bahwa sifat prolifik ini dikendalikan oleh gen fekunditas, yaitu gen BMP15. Pola pengontrolan gen terhadap mekanisme prolifisasi mengindikasikan adanya perbedaan antara breed kambing dan domba, tetapi sifat prolifik pada kambing dan domba masih dikontrol oleh gen yang sama yaitu BMP 15 (Chu et al., 2007). Hasil penelitian ini menunjukkan bahwa kambing lokal yang diamati terdapat korelasi polimorfisme gen $\mathrm{FecX}^{\mathrm{G}}$ atau gen BMP15 terhadap sifat prolifik pada kambing lokal yang menyebabkan adanya perbedaan litter size masing-masing genotipe kambing lokal.

\section{SIMPULAN}

Berdasarkan hasil PCR-RFLP dengan enzim restriksi HinfI (G|ANTC) terdapat mutasi gen $\mathrm{FecX}^{\mathrm{G}}$ pada kambing lokal. Terdapat korelasi polimorfisme gen $\mathrm{FecX}^{\mathrm{G}}$ terhadap sifat prolifik pada kambing lokal yang menyebabkan adanya perbedaan litter size masing-masing genotipe.

\section{DAFTAR PUSTAKA}

Chu, M.X., Liu, Z.H. Liu, C.L. Jiao, Y.Q. He, L. Fang, S.C. Ye, G.H. Chen and J.Y. Wang. 2007. Mutations in BMPR-IB and BMP-15 genes are associated with litter size in Small Tailed Han sheep (Ovis aries). Journal of Animal Science. 85:598603.

Davis G.H. 2005. Major Genes Effecting Ovulation Rate in Sheep. Journal Genetics Selection Evolution 37: S11-S23.

Davis, G.H., S.M. Galloway, I.K. Ross, S.M. Gregan, J. Ward, B.V. Nimbkar, P.M. Ghalsasi, C. Nimbkar, G.D. Gray, Subandriyo, I. Inounu, B. Tiesnamurti, E. Martyniuk, E. Eythorsdottir, P. Mulsant, F. Lecerf, J.P. Hanrahan, G.E. Bradford, and T. Wilson. 2002. DNA tests in prolific sheep from eight countries provide new evidence on origin of the Booroola (FecB) mutation. Biology Reproduction. 66:18691874.

Fabre, S., A. Pierre, P. Mulsant, L. Bodin, E. Di Pasquale, L. Persani, P. Monget, and D. Monniaux. 2006. Regulation of ovulation rate in mammals: Contribution of sheep genetic models. Biology Reproduction Endocrinology 4:20.

Hamdan, D.N., T.N. Siregar, B. Panjaitan dan Husnurrizal. 2012. Kinerja reproduksi kambing lokal yang diinduksi super-ovulasi dengan antiserum Inhibin. Jurnal Kedokteran Hewan 6(1):1-5.

Hartl, D.L., and A.G. Clark. 1997. Principles of Population Genetics. 3rd ed. Sinauer Associates. Inc. Publishers. Sunderland. Massachusetts.

Maskur dan C. Arman. 2010. Identifikasi mutasi gen BMPR-1B dan BMP15 pada 
domba ekor gemuk. Jurnal Ilmu Ternak dan Veteriner 15(1): 16-21.

Mendenhall, W. 1987. Inroduction to

Probability and Statistics. Seventh Ed.

PWS Publishers. 20 Park Plaza. Boston,

Massachusetts. USA.

Nei, M. 1987. Molecular Evolutionary Genetics. Columbia University Press. New York.

Nei, M. and S. Kumar. 2000. Molecular Evaluation and Phylogenetics. Oxford University Press, New York.

Pamungkas, F.A., A. Batubara, M. Doloksaribu dan E. Sihite. 2009. Petunjuk Teknis Potensi Beberapa Plasma Nutfah Kambing Indonesia. Pusat Penelitian dan Pengembangan Peternakan, Deli Serdang, Sumatera Utara.

Tambasco, D. D, M. Tambasco-Studart, A. P. Pereira, M.M. Alencar, A. R. Freitas, L. L. Countinho, I.U. Packer and L. C. A. Regitano. 2003. Candidate genes for growth traits in beef cattle Bos Taurus $\mathrm{x}$ Bos Indicus. Journal of Animal. Breeding and Genetics 120: 51-60.

Weir, B.S. 1996. Genetic data analysis II. Sinauer Associates. Sunderland. Massachusetts.

Wijosono, S.R, L.G.S. Astiti, T. Panjaitan, A. Muzani, N. Agustini. 2009. Beternak kambing intensif. Proseding Seminar Nasional. Balai Pengkajian Teknologi Pertanian, NTB. Badan Penelitian dan Pengembangan Pertanian. Departemen Pertanian. 
Jurnal Ilmu dan Teknologi Peternakan Indonesia

Rahmat Agus Hidayat, Sulaiman Ngongu Depamede, Maskur (Identifikasi Mutasi FecX...) 
